\title{
Analisis Keterampilan Proses Sains Siswa Pada Materi Pemantulan Pada Cermin Datar
}

\author{
Darmaji $^{1}$, Dwi Agus Kurniawan ${ }^{1}$, Astalini ${ }^{1}$, Heldalia $^{1}$ \\ ${ }^{1}$ Pendidikan Fisika-Universitas Jambi
}

\begin{tabular}{l} 
INFO ARTIKEL \\
\hline Riwayat Artikel: \\
Diterima: $14-04-2020$ \\
Disetujui: $21-07-2020$ \\
\hline
\end{tabular}

\section{Kata kunci:}

science process skills; reflection;

flat mirror;

keterampilan proses sains;

pemantulan;

cermin datar

\begin{abstract}
ABSTRAK
Abstract: The purpose of this study was to analyze students' science process skills in the reflection material on a flat mirror. The instrument used in this study was the observation sheet of science process skills. This type of research uses qualitative and quantitative research. With a sample of 84 students. Data were analyzed using SPSS 23 Program to get the average value of each indicator. Based on the results of this study, students' science process skills were classified as good at $27.93 \%$. Some students are less enthusiastic in the learning process and in practical activities are also still low.
\end{abstract}

\begin{abstract}
Abstrak: Tujuan penelitian ini adalah untuk menganalisis keterampilan proses sains siswa pada materi pemantulan pada cermin datar. Instrumen yang digunakan dalam penelitian ini adalah lembar observasi keterampilan proses sains. Jenis penelitian ini menggunakan penelitian kualitatif dan kuantitatif. Dengan sampel sebanyak 84 siswa. Pada penelitian ini digunakan uji statistik deskriptif. Berdasarkan hasil penelitian ini, keterampilan proses sains siswa tergolong baik yaitu 27,93\%. Sebagian siswa kurang berantusias dalam proses belajar dan dalam kegiatan praktikum keterampilan proses sains yang dimiliki siswa juga masih rendah.
\end{abstract}

\section{Alamat Korespondensi:}

Dwi Agus Kurniawan

Pendidikan Fisika

Universitas Jambi

Jalan Jambi-Muara Bulian No. Km. 15, Mendalo Darat, Kec. Jambi Luar Kota

E-mail: dwiagus.k@unja.ac.id

Pendidikan berperan penting dalam kehidupan karena dengan adanya pendidikan seseorang mampu memantaskan dirinya dengan layak baik di lingkungan keluarga maupun masyarakat. Selain itu, pendidikan adalah upaya persiapan yang dilakukan seseorang untuk memperoleh keterampilan, pengetahuan dan kebiasaan dalam hidup (Asrial et al., 2019). Hal ini mengharuskan pendidikan diharapkan terus dikembangkan secara terus menerus sesuai dengan perkembangan zaman (Astalini, Kurniawan, \& Putri, 2018). Menurut UU No. 20 tahun 2003, pendidikan adalah sebuah usaha yang dilakukan secara sadar dan terencana untuk mewujudkan suasana belajar dan proses pembelajaran agar peserta didik secara aktif mengembangkan potensi dirinya untuk memiliki kekuatan spiritual keagamaan, membangun kepribadian, pengendalian diri, kecerdasan, akhlak mulia, serta keterampilan diperlukan dirinya, masyarakat, bangsa, dan negara (Republik Indonesia, 2003).

Menurut Darmaji, Kurniawan, \& Suryani (2019) pendidikan adalah proses berkelanjutan yang bertujuan untuk meningkatkan kualitas sumber daya manusia. Melalui proses jenjang pendidikan berkelanjutan dari tingkat kanak-kanak hingga dewasa, pendidikan dapat meningkatkan kualitas sumber daya manusia. Untuk meningkatkan kualitas dari pendidikan jika ditinjau dari sistem pendidikan nasional, maka unsur-unsur dan faktor yang memengaruhi adalah faktor kurikulum, faktor guru, faktor sarana dan prasarana, faktor waktu, faktor uang, faktor tujuan, faktor metode, dan faktor lingkungan pendidikan (Rahim, 2015). Pendidikan di Indonesia telah disempurnakan dengan baik dan butuh pengembangan lebih lanjut. Kesinambungan pendidikan seharusnya berkaitan penuh dengan kurikulum yang digunakan. Menurut Astalini, Kurniawan, Melsayanti, \& Destianti (2018), kurikulum pendidikan yang digunakan selaras dengan sekolah yang ada. Kurikulum di sekolah sering berganti disebabkan karena sesuai atau tidak sesuai kurikulum saat diterapkan. Kurikulum saat ini yang digunakan yaitu kurikulum 2013 revisi sehingga peserta didik diinginkan memiliki sikap yang ilmiah dalam pembelajaran.

Menurut Puspita, Paidi, \& Nurcahyo (2017), kurikulum 2013 dirancang untuk mengembangkan potensi peserta didik secara utuh. Berdasarkan kurikulum 2013 peserta didik dituntut untuk belajar lebih bermakna karena aspek yang dikembangkan pada kurikulum saat ini bukan hanya pada pengetahuan dan nilai melainkan berupa keterampilan dalam menemukan konsep dan fakta-fakta yang ada. Keterampilan menemukan konsep dapat kita lihat pada pelajaran fisika. Fisika merupakan salah satu mata pelajaran wajib untuk peserta didik di tingkat SMA Sederajat. Menurut Astuti (2015), fisika dipandang sebagai suatu proses dan produk, sehingga strategi atau metode pembelajaran yang digunakan harus efektif dan efisien. Pembelajaran fisika tidak hanya mempelajari tentang konsep-konsep, penguasaan kumpulan pengetahuan yang berupa fakta alam, atau prinsip-prinsip saja, tetapi merupakan suatu proses penemuan. Astalini, et al (2019), fisika telah menjadi salah satu mata pelajaran yang terkait 
dengan konsep ilmiah. Dengan demikian, peserta didik dituntut harus mengikuti dan menguasai materi fisika yang diajarkan karena fisika berperan penting dalam mengembangkan sikap ilmiah peserta didik. Dalam pembelajaran fisika, pembelajaran tidak hanya teori yang harus diberikan, tetapi dibiasakan untuk mampu memahami masalah fisika dari mulai matematisnya sampai mengetahui arti fisisnya.

Menurut Rustam \& Kamaruzzaman (2016), pembelajaran merupakan proses kegiatan belajar mengajar di sekolah yang terdiri dari guru dan siswa sebagai pelaku aktif. Guru adalah orang yang memberikan ilmu kepada siswa serta melakukan penilaian dan evaluasi, sedangkan siswa adalah orang yang menerima ilmu yang sudah terdaftar secara resmi untuk mengikuti pelajaran di sekolah. Ada dua faktor yang memengaruhi proses pembelajaran, yaitu internal dan eksternal. Faktor internal merupakan faktor yang berasal dari dalam diri siswa, faktor internal memiliki dua aspek, yaitu aspek fisiologis (jasmani, mata dan telinga) dan aspek psikologis inteligensi siswa, sikap siswa, bakat siswa, minat siswa, dan motivasi siswa, sedangkan faktor eksternal yaitu dari lingkungan sekitar (Darmaji, et al., 2019). Proses pembelajaran merupakan kegiatan belajar yang dilakukan siswa. Menurut Astalini, Kurniawan, Sari, \& Kurniawan (2019), pendidikan kegiatan belajar merupakan salah satu faktor penting dalam memengaruhi hasil belajar. Salah satu dari sekian banyak proses pembelajaran adalah pembelajaran fisika. Pembelajaran fisika diasumsikan penting untuk dipahami dan dipelajari sehingga pada perguruan tinggi terdapat pendidikan lanjutan mengenai fisika yaitu adanya program studi khusus Pendidikan Fisika (Sayekti, 2016). Physics is one of the subjects that presents natural phenomena and real change. Where physics is known as a difficult and difficult subject for students (Maison et al., 2019). Menurut Young, dkk (2002), terdapat dua penyebab kita harus belajar fisika, yaitu (1) merupakan salah satu ilmu pengetahuan paling dasar yaitu ilmu fisika dan (2) semua ilmu teknologi dan ilmu rekayasa merupakan dasar dari pembelajaran. Pembelajaran fisika dapat menjadi tempat untuk melatih kemampuan berpikir pada mahasiswa. Untuk mencapai tujuan tersebut diperlukan sumber belajar dan model pembelajaran yang sesuai (Suparwoto, 2007). Sumber, media, dan pembelajaran yang baik sangat membantu dalam pembentukan keterampilan bagi mahasiswa termasuk keterampilan proses sains.

Keterampilan proses sains merupakan keterampilan yang dapat digunakan seseorang untuk memperoleh informasi sehingga dapat menemukan hal-hal baru yang bermanfaat berupa fakta, konsep maupun pengembangan dalam pembelajaran. Melalui keterampilan proses sains konsep yang diperoleh peserta didik akan lebih bermakna karena keterampilan dalam berpikir peserta didik akan lebih berkembang (Budiyono \& Hartini, 2016). Keterampilan proses sains merupakan keterampilan yang sangat dibutuhkan \& dimiliki oleh siswa untuk menghadapi persaingan antar manusia di era globalisasi. Menurut Manu \& Nomleni (2018), keterampilan proses sains adalah perangkat kemampuan kompleks yang biasa digunakan oleh para ilmuwan dalam melakukan penyelidikan ilmiah ke dalam rangkaian proses pembelajaran. Hutagalung (2013), keterampilan proses sains adalah kemampuan siswa untuk menerapkan metode ilmiah dalam memahami, mengembangkan dan menemukan ilmu pengetahuan. Wulaningsih, Prayitno, \& Probosari (2012), keterampilan proses sains mendorong siswa untuk menemukan sendiri fakta, konsep pengetahuan serta menumbuhkembangkan sikap dan nilai yang dituntut.

Keterampilan proses sains yaitu pemahaman konsep ilmiah dengan melakukan tindakan dan pemikiran ilmiah untuk mendapatkan kemampuan-kemampuan berikutnya (Maison, Astalini, Kurniawan, \& Sholihah, 2018). According to Hirça (2013), science process skills have two categories, basic science process skills and integration science process skills. Turiman dkk (2012), menjelaskan keterampilan proses sains terdiri dari keterampilan proses dasar (mengamati, merangkum, mengukur, mendeskripsi, mengomunikasikan, mengklasifikasikan, memprediksi, menggunakan hubungan ruang waktu dan menggunakan angka adalah bagian dari keterampilan proses dasar) dan keterampilan proses terpadu (mengidentifikasi variabel, membangun tabel data, membangun grafik, menggambarkan hubungan antar variabel, memperoleh dan memproses data, menganalisis investigasi, membangun hipotesis, mendefinisikan variasi secara operasional, merancang penyelidikan, dan bereksperimen). Özgelen (2012), explains that science process skills are skills for gaining knowledge, solving problems and communicating results obtained this means that process skills consist of the ability to process scientific thought and the ability to process deep actionsto develop understand scientific concepts. So according to Darmaji, Kurniawan, Parasdila, \& Irdianti (2018), et aldevelopmentof scientific concepts that will support the nextabilities such as creativity, critical thinking skills, and greater accuracy or abilities, where such abilities are often used and found in everyday life.

Keterampilan proses sains penting untuk bisa diterapkan, hal ini sesuai dengan pernyataan Semiawan (1992), bahwa ada beberapa alasan mengapa pendekatan keterampilan proses sains itu diterapkan. Pertama, berkembangannya ilmu pengetahuan berlangsung begitu cepat sehingga tidak mungkin lagi guru mengajarkan fakta dan konsep kepada peserta didik. Kedua, adanya kecendrungan peserta didik mudah memahami konsep-konsep yang rumit jika disertai contoh yang konkret. Ketiga, penemuan tidak bersifat mutlak, tetapi bersifat relatif sehingga dapat terbantah apabila ada yang mendapatkan data baru yang mampu membuktikan kekeliruan. Dalam aktivitas pembelajaran dan praktikum keterampilan proses sains sangat diperlukan untuk membantu mahasiswa dalam memahami konsep-konsep suatu materi. It can be agreed that if students do not master or have Basic and integrated process skills then it will be difficult for students to develop better abilities and this will affect students become a teacher (Darmaji, Kurniawan, Parasdila, \& Irdianti, 2018).

Keterampilan proses sains merupakan keterampilan yang sangat dibutuhkan dalam kegiatan praktikum (Rahmawati, Handayanto, \& Dasna, 2018). Juga dijelaskan Hartono \& Oktafianto (2014), keterampilan proses dan sikap ilmiah dapat dikembangkan dengan memberikan pengalaman langsung kepada siswa. Salah satunya melalui kegiatan praktikum atau eksperimen. Praktikum dapat memberikan pembelajaran yang lebih mudah dipahami serta pengalaman konkrit, berdiskusi 
dengan teman sebaya sehingga siswa memperoleh pemahaman baru dengan melakukan kegiatan praktikum. Menurut (Hamidah, Sari, \& Budianingsih (2014) praktikum merupakan salah satu strategi pembelajaran yang dapat menarik minat siswa dalam mengembangkan konsep-konsep karena praktikum dapat memberikan pengalaman langsung kepada siswa untuk mengamati suatu fenomena yang terjadi sehingga siswa akan lebih memahami konsep yang diajarkan. Sementara itu, menurut Jaya (2010), kegiatan praktikum merupakan salah satu faktor penting yang dapat membantu keberhasilan siswa dalam mengikuti proses kegiatan pembelajaran. Selain memberikan pengalaman secara langsung, melalui kegiatan praktikum siswa juga mampu mengembangkan keterampilan. Menurut Ariyati (2012), pembelajaran melalui praktikum menjadi pilihan pembelajaran yang baik bagi peserta didik untuk mengembangkan keterampilan. Pembelajaran fisika sebagai proses yakni berupa keterampilan yang dimiliki oleh siswa untuk mencapai produk sains. Dengan demikian, keterampilan yang harus dimiliki siswa dalam pembelajaran fisika dan dapat dilaksanakan melalui kegiatan praktikum adalah keterampilan proses sains.

Keterampilan proses sains adalah semua kemampuan yang diperlukan untuk memperoleh, mengembangkan, dan menerapkan konsep-konsep, prinsip-prinsip, hukum-hukum, dan teori-teori sains baik berupa kemampuan mental, fisik, maupun kemampuan sosial. Melalui keterampilan proses, konsep yang diperoleh siswa akan lebih bermakna karena siswa menemukan sendiri konsep-konsep yang dipelajari melalaui tahap demi tahap. Pembelajaran akan lebih bermakna jika siswa diberi kesempatan untuk tahu dan terlibat secara aktif dalam menemukan konsep dari fenomena yang ada dari lingkungan dengan bimbingan guru (Rizal, 2014). Hal ini juga dijelaskan (Nworgu \& Otum, 2013), bahwa keterampilan proses sains sangat penting bagi setiap mahasiswa sebagai bekal untuk menggunakan metode ilmiah dalam mengembangkan sains serta diharapkan memperoleh pengetahuan baru atau mengembangkan pengetahuan yang telah dimiliki. Dengan pengetahuan dan keterampilan yang bagus akan mengikuti perkembangan zaman. Seperti yang kita lihat pada era revolusi 4.0 berbagai teknologi telah berkembang dengan sangat pesat. Today's education requires the use of technology to develop and improve human resource improvement competencies. because now is the era of industrial renewal lament 4.0 (Astalini, Kurniawan, Sulistiyo, Perdana, \& Susbiyanto, 2019). Ilmu Pengetahuan Alam terdiri dari Biologi, Kimia dan Fisika. Di setiap pelajaran tersebut membutuhkan keterampilan proses sains dalam menyelesaikan sebuah masalah. Maka dari itu, tujuan dari penelitian ini yaitu menganalisis prakiraan keterampilan proses sains siswa pada materi pemantulan pada cermin datar.

\section{METODE}

Jenis penelitian ini menggunakan penelitian kualitatif dan kuantitatif. Dalam penelitian kuantitatif digunakan prosedur penelitian survei. Agar lebih mendetail, penelitian jenis kualitatif juga dilakukan, yakni menggunakan teknik wawancara. Penelitian ini digunakan berdasarkan tujuan penelitian ini yaitu mengetahui deskripsi keterampilan proses sains siswa SMAN 7 Kota Jambi terhadap mata pelajaran Fisika.

Instrumen yang digunakan dalam penelitian ini adalah lembar observasi keterampilan proses sains dengan peserta didik sejumlah 84 siswa kelas XI SMA di kota Jambi. Pada keterampilan proses sains ini diukur berdasarkan praktikum yang dilakukan pada pelajaran fisika yang membahas tentang materi pemantulan pada cermin datar, yang sesuai dengan indikator keterampilan proses sains siswa. Interval penguasaan kemampuan keterampilan proses yang diukur pada penelitian ini dapat dilihat pada tabel 1. Lembar observasi keterampilan proses sains dalam penelitian ini menggunakan format yang diadaptasi dari peneltian John, Molepo \& Chirwa (2016) dengan jumlah soal sebanyak 8. Suatu gambaran atau penyajian data dalam jumlah besar yang mencakup mean, modus, median, maksimum, minimum, dan standar deviasi merupakan statistik deskriptif. Data dianalisis menggunakan Program SPSS 21 untuk memperoleh mean, modus, median, maksimum, minimum.

Pelaksanaan penelitian ini dilakukan pada bulan Oktober. Penelitian ini menggunakan teknik pengambilan sampel, yaitu sampling. Keterampilan proses sains yaitu sebuah pemahaman konsep ilmiah dengan melakukan suatu tindakan dan pemikiran ilmiah untuk mendapatkan kemampuan-kemampuan berikutnya. Keterampilan proses sains siswa dapat dilihat dari kegiatan praktikum karena dalam praktikum melibatkan siswa dalam penggunaan alat laboratorium yang digunakan untuk menemukan konsep fisika untuk individu dan kelompok terdapat 16 indikator keterampilan proses sains yang digunakan pada penelitian ini. Berikut tabel interval penguasaan keterampilan proses sains siswa (Tabel 1).

Tabel 1. Interval Pengusaan Keterampilan Proses Sains Siswa

\begin{tabular}{lll}
\hline No & Interval & Kategori \\
\hline 1 & $1,00-1,75$ & Sangat Tidak Baik \\
2 & $1,76-2,50$ & Tidak Baik \\
3 & $2,51-3,25$ & Baik \\
4 & $3,26-4,00$ & Sangat Baik \\
\hline
\end{tabular}


HASIL

Hasil dari data keterampilan proses sains siswa dalam praktikum pemantulan pada cermin datar dapat dilihat pada tabel 2.

Tabel 2. Deskripsi Keterampilan Proses Sains Dasar pada Praktikum Materi Pemantulan Pada Cermin Datar

\begin{tabular}{clcccc}
\hline \multirow{2}{*}{ Keterampilan Proses Sains } & \multicolumn{1}{c}{ Indikator } & \multicolumn{3}{c}{ Kategori } \\
\cline { 2 - 5 } & & STB (\%) & TB (\%) & B (\%) & SB (\%) \\
\cline { 2 - 5 } & Observasi & 0 & 9,5 & 47,6 & 42,9 \\
& Klasifikasi & 14,3 & 27,4 & 48,8 & 9,5 \\
& Mengukur & 0 & 42,9 & 26,2 & 31,0 \\
& Prediksi & 4,8 & 52,4 & 29,8 & 13,1 \\
& Komunikasi & 32,1 & 22,6 & 26,6 & 18,7 \\
& Menyimpulkan & 7,1 & 14,3 & 48,8 & 29,8 \\
\hline & Membuat Grafik & 5,6 & 27,8 & 33,3 & 33,3 \\
& Memperoleh dan & 16,7 & 34,5 & 22,6 & 26,2 \\
& Memproses Data & 14,3 & 19,0 & 58,3 & 8,3 \\
& Menyususn Tabel Data & 28,6 & 33,3 & 3,7 & 2,4 \\
& Membuat Hipotesis & 14,3 & 19,0 & 58,3 & 8,3 \\
& Analisis Percobaan & 16,7 & 21,4 & 41,7 & 20,2 \\
& Merancang Investigasi & 26,2 & 23,8 & 21,4 & 28,6 \\
& Menganalisis Investigasi & 7,1 & 13,1 & 31,0 & 48.8 \\
\hline Melakukan Eksperimen & & & & \\
\hline
\end{tabular}

Hasil dari analisis keterampilan proses sains pada setiap indikator. Indikator keterampilan proses sains dasar, meliputi observasi, klarifikasi, mengukur, prediksi, komunikasi, dan menyimpulkan. Sementara itu, indikator dari keterampilan proses sains terintegrasi yaitu membuat grafik, memperoleh data dan memproses data, menyusun tabel data, mengidentifikasi variabel, mendeskripsikan variabel secara operasional, membuat hipotesis, analisis percobaan, merancang investigasi, menganalisis investigasi, dan melakukan eksperimen.

\section{Observasi}

Pada indikator keterampilan observasi berada dalam kategori baik dengan nilai persentase 47,6\%. Observasi adalah kegiatan mengumpulkan fakta yang relevan dengan menggunakan sebanyak mungkin indra. Pada indikator keterampilan observasi peserta didik mengamati dan meraba alat dan bahan yang akan diujicobakan pada kegiatan praktikum pemantulan pada cermin datar, mengamati dengan cermat tancapan jarum U dan V di sebelah kiri benda (S) untuk melihat bayangan pada cermin, mengamati dengan cermat tancapan jarum W dan X di sebelah kanan benda (S) untuk melihat bayangan pada cermin, mengamati jarum $\mathrm{U}$ dan $\mathrm{V}$ yang segaris lurus, mengamati jarum $\mathrm{W}$ dan $\mathrm{X}$ yang segaris lurus, mengamati jarak bayangan, mengamati jarak benda, mengamati sudut datang dan sudut pantul yang terbentuk, mengamati data dalam tabel untuk membuat grafik hubungan variabel pada percobaan pemantulan pada cermin datar. Pada indikator ini siswa sudah mengamati kegiatan observasi dengan baik.

\section{Klasifikasi}

Pada indikator keterampilan klasifikasi berada dalam kategori baik dengan nilai persentase 48,8\%. Klasifikasi adalah kegiatan mencatat setiap pengamatan secara terpisah, mencari perbedaan, persamaan, mengontraskan ciri-ciri, membandingkan, mencari dasar pengelompokkan atau penggolongan dan menghubungkan hasil-hasil pengamatan. Pada indiaktor ini terlihat bahwa peserta didik sudah terampil dalam mengklasifikasikan karakteristik data percobaan.

\section{Mengukur}

Pada indikator keterampilan mengukur berada dalam kategori tidak baik dengan nilai persentase 42,9\%. Mengukur adalah kegiatan mengukur setiap besaran yang ada. Pada indikator keterampilan mengukur peserta didik mengukur jarak benda, peserta didik mengukur jarak bayangan ke cermin, peserta didik mengukur besar sudut datang, peserta didik mengukur besar sudut pantul. Pada indikator keterampilan mengukur sebagian peserta didik masih salah dalam kegiatan mengukur. Hal ini disebabkan karena kurang teliti dalam kegiatan mengukur dan pembacaan dalam pengukuran yang masih salah. 


\section{Prediksi}

Pada indikator keterampilan prediksi berada dalam kategori tidak baik dengan nilai persentase $52,4 \%$. Prediksi adalah Mengemukakan apa yang mungkin terjadi pada keadaan yang belum diamati dengan menggunakan pola hasil pengamatan. Pada indikator keterampilan prediksi peserta didik Peserta didik membuat prediksi bagaimana hubungan antara jarak benda (S) dan jarak bayangan (S') serta sudut datang dan sudut pantulnya. Pada indikator prediksi peserta didik masih belum benar dalam memprediksi keadaan.

\section{Komunikasi}

Pada indikator keterampilan komunikasi berada dalam kategori sangat tidak baik dengan nilai persentase 32,1\%. Komunikasi adalah kegiatan dalam menggambarkan data empiris hasil percobaan atau pengamatan mempresentasikan hasil yang diperoleh. Pada indikator keterampilan komunikasi peserta didik mendiskusikan hasil pengukuran dengan teman kelompoknya dan peserta didik mempresentasikan hasil percobaan. Dalam indikator ini siswa masih kurang terampil dalam mempresentasikan hasil yang didapat sementara dalam diskusi masih ada peserta didik yang kurang berpartisispasi atau tidak aktif dalam kegiatan diskusi.

\section{Menyimpulkan}

Pada indikator keterampilan menyimpulkan berada dalam kategori baik dengan nilai persentase $48,8 \%$. Menyimpulkan adalah kegiatan mengambil kesimpulan dari kegiatan yang dilakukan. Pada indikator keterampilan menyimpulkan peserta didik mengutarakan sifat-sifat bayangan yang terbentuk oleh cermin datar, peserta didik mengutarakan hubungan jarak benda dan jarak bayangan yang dibentuk oleh cermin datar, peserta didik mengutarakan nilai jarak bayangan yang dibentuk oleh cermin datar, peserta didik mengutarakan nilai jarak benda ke cermin, peserta didik mengutarakan nilai sudut datang pada cermin datar, peserta didik mengutarakan nilai sudut pantul yang dibentuk oleh cermin dan peserta didik mengaitkan hasil praktik berdasarkan teori. pada indikator ini poeserta didik sudah bisa menyimpulkan hasil kegiatan dengan baik dan menjelaskan setiap hasil yang didapat dengan rinci.

\section{PEMBAHASAN}

Keterampilan proses sains dibutuhkan dalam pembelajaran abad 21 sebagai tindakan dalam membantu siswa mengembangkan kemampuan penyelidikannya. Menurut Damopolii (2014) kegiatan pembelajaran yang menggunakan inkuiri membantu siswa memahami secara lebih mendalam materi yang diajarkan. Selanjutnya, Ariani, Hamid, \& Leny (2015), dalam penelitiannya menemukan bahwa meningkatnya pencapaian hasil belajar siswa, diakibatkan adanya peningkatan keterampilan proses sains pada siswa. Berdasarkan data hasil penelitian ditemukan bahwa KPS siswa mengalami suatu peningkatan yang baik. Peningkatan KPS diikuti dengan adanya peningkatan pencapaian ketuntasan hasil belajar siswa. Hal ini juga dijelaskan Nworgu \& Otum (2013), bahwa keterampilan proses sains sangat penting bagi setiap mahasiswa sebagai bekal untuk menggunakan metode ilmiah dalam mengembangkan sains serta diharapkan memperoleh pengetahuan baru atau mengembangkan pengetahuan yang telah dimiliki. Dengan pengetahuan dan keterampilan yang bagus akan mengikuti perkembangan zaman. Seperti yang kita lihat pada era revolusi 4.0 berbagai teknologi telah berkembang dengan sangat pesat. Today's education requires the use of technology to develop and improve human resource improvement competencies. because now is the era of industrial renewal lament 4.0 (Astalini, Kurniawan, Sulistiyo, et al., 2019). Siswa terampil melakukan percobaan untuk mengetahui bagaimana proses gerak refleks terjadi. Siswa terlibat langsung dalam pengalamannya. Akibat dari pengalaman yang dialami siswa, membuat konsep tentang gerak refleks bertahan lama dalam otak siswa.

Berdasarkan wawancara yang dilakukan peneliti mengenai keterampilan proses sains siswa kelas XI MIA SMAN 1 Kota Jambi pada saat proses pembelajaran Fisika berlangsung. Hasil observasi di SMAN 7 Kota Jambi ditemukan dalam proses pembelajaran siswa sebagian banyak cenderung diam saja mengenai materi yang disampaikan, pada saat guru menanyai mengenai pemahaman materi siswa hanya diam dan ada beberapa yang mengatakan mengerti, proses pembelajaran fisika kurang mengaktifkan siswa. Aktivitas siswa cenderung rendah yang diakibatkan oleh pemilihan strategi dan metode pembelajaran kurang tepat serta tidak bervariatif. Fakta ini menyebabkan kemampuan berpikir khususnya kemampuan berpikir kritis dan keterampilan proses sains siswa juga rendah. Penjelasan di atas terjadi karena siswa kurang aktif dalam kegiatan pembelajaran sehingga keterampilan proses sains siswa masih tergolong rendah pada pelajaran Fisika. Pada hasil penelitian didapatkan hasil pada kategori baik 27,93\% dan kategori tidak baik 26,88 \%. Dari hasil data dan hasil wawancara tersebut menunjukkan bahwa sebagian siswa masih kurang dalam keterampilan proses sains

Jadi, dari penelitian yang telah dilakukan diperoleh hasil yang baik. Siswa dapat menuliskan hasil pengukuran pada tabel percobaan sesuai dengan data eksperimen yang diperoleh saat melakukan praktikum, siswa dapat mengobservasi, mengklarifikasi, mengukur, memprediksi, mengomunikasi, menyimpulkan, membuat grafik, memperoleh data dan memproses data, memyusun tabel data, mengidentifikasi variabel, mendeskripsikan variabel secara operasional, membuat hipotesis, menganalisis percobaan, merancang investigasi, menganalisis investigasi dan melakukan eksperimen. Sikap ilmiah yang dimiliki oleh mahasiswa sangat memengaruhi pada kegiatan praktikum. 


\section{SIMPULAN}

Secara keseluruhan, keterampilan proses sains siswa dalam mengobservasi, mengklarifikasi, mengukur, memprediksi, mengomunikasikan, menyimpulkan, membuat grafik, memperoleh data dan memproses data, menyusun tabel data, mengidentifikasi variabel, mendeskripsikan variabel secara operasional, membuat hipotesis, menganalisis percobaan, merancang investigasi, menganalisis investigasi dan melakukan eksperimen tergolong dalam kategori baik dengan persentase $27,93 \%$, kategori sangat tidak baik dengan persentase 26,88\%, kategori sangat baik dengan persentase $21,11 \%$ dan kategori sangat tidak baik dengan persentase $13,23 \%$. Hasil penelitian ini menunjukkan bahwa masih perlu peningkatan keterampilan pada siswa yaitu dapat membuat pembelajaran menjadi lebih menarik, memilih model pembelajaran yang sesuai dengan keinginan siswa dan perlengkapan alat pembelajaran. Penelitian kedepannya agar dapat menggunakan pembelajaran yang lebih baik untuk melatih dan mengembangkan keterampilan proses sains yang masih tergolong rendah, seperti pada indikator mengukur, memprediksi, mengomunikasi, mengidentifikasi variabel, mendeskripsikan variabel secara operasional, membuat hipotesis, dan menganalisis investigasi.

\section{DAFTAR RUJUKAN}

Aditya, R. P., Paidi., \& Nurcahyo. (2017). Analisis Keterampilan Proses Sains LKPD Sel di SMA Negeri, 6(3), 164-170.

Ariani, M., Hamid, A., \& Leny. (2015). Meningkatkan Keterampilan Proses Sains dan Hasil Belajar Siswa pada Materi Koloid dengan Model Inkuiri Terbimbing (Guided Inquiry) pada Siswa Kelas XI IPA 1 SMA Negeri 11 Banjarmasin. Quantum (Jurnal Inovasi Pendidikan Sains), 6(1), 98-107.

Ariyati, E. (2012). Pembelajaran Berbasis Praktikum untuk Meningkatkan Kemampuan Berpikir Kritis Mahasiswa. Jurnal Pendidikan Matematika dan IPA, 1(2), 1-12. https://doi.org/10.26418/jpmipa.v1i2.194

Asrial., Syahrial., Kurniawan, D. A., Chan, F., Septianingsih, R., \& Perdana, R. (2019). Multimedia Innovation 4.0 in Education: E-modul Ethnoconstructivism. Universal Journal of Educational Research, 7(10), 2098-2107. https://doi.org/10.13189/ujer.2019.071007

Astalini, A., Kurniawan, D. A., Melsayanti, R., \& Destianti, A. (2018). Sikap terhadap Mata Pelajaran IPA di SMP seKabupaten Muaro Jambi. Lentera Pendidikan: Jurnal Ilmu Tarbiyah dan Keguruan, 21(2), 214. https://doi.org/10.24252/lp.2018v21n2i7

Astalini, A., Kurniawan, D. A., \& Putri, A. D. (2018). Identifikasi Sikap Implikasi Sosial dari IPA, Ketertarikan Menambah Waktu Belajar IPA, dan Ketertarikan Berkarir di Bidang IPA Siswa SMP Se-Kabupaten Muaro Jambi. Jurnal Tarbiyah: Jurnal Ilmiah Kependidikan, 7(2), 93-108. https://doi.org/10.18592/tarbiyah.v7i2.2142

Astalini, A., Kurniawan, D. A., Sari, D. K., \& Kurniawan, W. (2019). Description of Scientific Normality, Attitudes of Investigation and Interested Career on Physics in Senior High School. JIPF (Jurnal Ilmu Pendidikan Fisika), 4 (2), 56. https://doi.org/10.26737/jipf.v4i2.885

Astalini, Kurniawan, D. A., Darmaji, Sholihah, L. R., \& Perdana, R. (2019). Characteristics of Students' Attitude to Physics in Muaro Jambi High School. Humanities and Social Sciences Reviews, 7(2), 91-99. https://doi.org/10.18510/hssr.2019.7210

Astalini, Kurniawan, D. A., Sulistiyo, U., Perdana, R., \& Susbiyanto. (2019). E-assessment Motivation in Physics Subjects for Senior High School. International Journal of Online and Biomedical Engineering, 15(11), 4-15. https://doi.org/10.3991/ijoe.v15i11.10843

Astuti, S. P. (2015). Pengaruh Kemampuan Awal dan Minat Belajar terhadap Prestasi Belajar Fisika. Formatif: Jurnal Ilmiah Pendidikan MIPA, 5(1), 68-75. https://doi.org/10.30998/formatif.v5i1.167

Budiyono, A., \& Hartini, H. (2016). Pengaruh Model Pembelajaran Inkuiri Terbimbing terhadap Keterampilan Proses Sains Siswa SMA. Wacana Didaktika, 4(2), 141-149. https://doi.org/10.31102/wacanadidaktika.4.2.141-149

Cresswel, John W. (2012). Educational Research: Planning, Conducting, And Evaluating Quantitative And Qualitative Research. New York: Pearson.

Damopolii, I. (2014). Pengaruh Strategi Pembelajaran Inkuiri dan Kemampuan Memecahkan Masalah terhadap Keterampilan Proses Sains Mahasiswa pada Praktikum Fisiologi Tumbuhan. Jurnal Natural, 13(3). https://doi.org/10.30862/jn.v13i3.726

Darmaji, Astalini, Kurniawan, D. A., Parasdila, H., Iridianti, Susbiyanto, ... Ikhlas, M. (2019). E-Module Based Problem Solving in Basic Physics Practicum for Science Process Skills. International Journal of Online and Biomedical Engineering, 15(15), 4-17. https://doi.org/10.3991/ijoe.v15i15.10942

Darmaji, D., Kurniawan, D. A., Parasdila, H., \& Irdianti, I. (2018a). Deskripsi Keterampilan Proses Sains Mahasiswa pada Materi Termodinamika. Berkala Ilmiah Pendidikan Fisika, 6(3), 345-353. https://doi.org/10.20527/BIPF.V6I3.5290

Darmaji, D., Kurniawan, D. A., \& Suryani, A. (2019). Effectiveness of Basic Physics II Practicum Guidelines Based on Science Process Skills. JIPF (Jurnal Ilmu Pendidikan Fisika), 4(1), 1. https://doi.org/10.26737/jipf.v4i1.693

Darmaji, Kurniawan, D. A., Parasdila, H., \& Irdianti. (2018b). Description of Science Process Skills' Physics Education Students at Jambi University in Temperature and Heat Materials. Educational Review, USA, 2(9), 485-498. https://doi.org/10.26855/er.2018.09.004 
Hamidah, A., Sari, E. N., \& Budianingsih, R. S. (2014). Persepsi Siswa tentang Kegiatan Praktikum Biologi di Laboratorium SMA Negeri Se-Kota Jambi. Jurnal Sainmatika, 8(1), 49-59. https://doi.org/10.1017/CBO9781107415324.004

Hartono, \& Oktafianto, W. R. O. (2014). Kefektifan Pembelajaran Praktikum IPA Berbantu LKS Discovery untuk Mengembangkan Keterampilan Proses Sains. Unnes Physics Education Journal, 3(1).

Hirça, N. (2013). The Influence of Hands on Physics Experiments on Scientific Process Skills According to Prospective Teachers' Experiences. European Journal of Physics Education, 4(1), 1-9.

Hutagalung, A. M. (2013). Efek Model Pembelajaran Inquiry Training Berbasis Media Komputer terhadap Keterampilan Proses Sains dan Kemampuan Berpikir Kritis Siswa. Jurnal Pendidikan Fisika, 2(2), 9. https://doi.org/10.22611/jpf.v2i2.3473

John, M., Molepo, J. M., \& Chirwa, M. (2016). How Do Learners Conceptualize Plane Mirror Reflection? A Case Study of Grade 11 South African Learners. International Journal of Education Sciences, 13(2), 221-230

Maison, Astalini, Darmaji, Kurniawan, D. A., Perdana, R., \& Anggraini, L. (2019). The Phenomenon of Physicology Senior High School Education: Relationship of Students' Attitudes Toward Physic, Learning Style, Motivation. Universal Journal of Educational Research, 7(10), 2199-2207. https://doi.org/10.13189/ujer.2019.071018

Manu, T. S. N., \& Nomleni, F. T. (2018). Pengaruh Metode Pembelajaran Karya Kelompok terhadap Keterampilan Proses Sains dengan Kovariabel Kemampuan Berpikir Kreatif Siswa pada Mata Pelajaran Biologi. Scholaria: Jurnal Pendidikan dan Kebudayaan, 8(2), 167-179. https://doi.org/10.24246/j.js.2018.v8.i2.p167-179

Nworgu, L. N., \& Otum, V. V. (2013). Effect of Guided Inquiry with Analogy Instructional Strategy on Students Acquisition of Science Process Skills. Journal of Education and Practice, 4(27), 35-41.

Özgelen, S. (2012). Students' Science Process Skills within a Cognitive Domain Framework. Eurasia Journal of Mathematics, Science and Technology Education, 8(4), 283-292. https://doi.org/10.12973/eurasia.2012.846a

Rahim, A. (2015). Strategi Peningkatan Kualitas Pendidikan di Madrasah Aliyah Kabupaten Sidrap: Tinjauan Implementasi Kurikulum Tingkat Satuan Pendidikan. Lentera Pendidikan: Jurnal Ilmu Tarbiyah dan Keguruan, 18(2), $218-235$.

Rahmawati, Handayanto, S. K., \& Dasna, I. W. (2018). Pengaruh Learning Cycle 5E Terhadap Keterampilan Proses Sains Peserta Didik Kelas VIII. Jurnal Pendidikan:Teori, Penelitian, dan Pengembangan, 3(3), 286-290.

Rizal. (2014). Pengaruh Pembelajaran Inkuiri Terbimbing dengan Mind Map terhadap Keterampilan Proses Sains dan Hasil Belajar IPA. Jurnal Pendidikan Sains, 2(4), 159-165.

Rustam, \& Kamaruzzaman. (2016). Meningkatkan Tanggung Jawab Belajar melalui Layanan Bimbingan Kelompok dengan Teknik Proyeksi. Jurnal Penelitian Tindakan Bimbingan \& Konseling, 2(2), 1-8.

Sayekti, I. (2016). Pembelajaran IPA Menggunakan Inkuiri Terbimbing Melalui Eksperimen dan Demonstrasi Ditinjau dari Kemampuan Analisis Siswa. Jurnal Pendidikan Sains, 4(1), 6-16. https://doi.org/10.26714/jps.4.1.2016.6-16

Semiawan, C. (1989). Pendekatan Keteranpilan Proses, Bagaimana Mengaktifkan Siswa dalam Belajar. Jakarta: Gramedia Suparwoto. (2007). Pengembangan Bahan Ajar Bahan Kuliah Online. Bandung: Direktori UPI.

Turiman, P., Omar, J., Daud, A. M. \& Osman, K. 2012. Fostering the $21^{\text {st }}$ Century Skills through Scientific Literacy and Science Process Skills. Procedia-Social and Behavioral Sciences, 59, 110-116.

Wulaningsih, S., Prayitno, B. A., \& Probosari, R. M. (2012). Pengaruh Model Pembelajaran Inkuiri Terbimbing terhadap Keterampilan Proses Sains Ditinjau dari Kemampuan Akademik Siswa Science Process Skills Viewed From Student's Academic. Pendidikan Biologi, 4(2), 33-43. https://doi.org/10.1161/RES.0b013e31821e0b53

Undang-Undang RI Nomor 20 Tahun 2003 tentang Sistem Pendidikan Nasional. 2003. Jakarta: Sekretariat Negara. 